\title{
Notes on the taxonomy and nomenclature of Monotrema bracteatum (Rapateaceae)
}

\author{
Rodrigo Schütz Rodrigues ${ }^{1}$ \\ 1. Universidade Federal de Roraima, Centro de Estudos da Biodiversidade, Campus do Paricarana, Av. Ene Garcez \\ 2413, CEP 69310-000, Boa Vista, Roraima, Brasil. E-mail: rodrigo.schutz@ufrr.br
}

Recebido em: 11/08/2015 Aceito em: 31/08/2015 Publicado online em PDF: 21/09/2015.

\section{RESUMO}

Notas sobre a taxonomia e nomenclatura de Monotrema bracteatum (Rapateaceae). Monotrema é um pequeno gênero de Rapateaceae que abrange quatro espécies. Esta nota discute aspectos taxonômicos e nomenclaturais de Monotrema bracteatum Maguire, uma espécie recentemente registrada para o Brasil, que ocorre em campinas de areias brancas no estado de Roraima. .

PALAVRAS-CHAVE: Amazônia, Brasil, Escudo das Guianas, Poales, Roraima

\section{ABSTRACT}

Notes on the taxonomy and nomenclature of Monotrema bracteatum (Rapateaceae). Monotrema is a small genus of Rapateaceae comprising four species. This note discusses taxonomic and nomenclatural aspects of Monotrema bracteatum Maguire, a species recently recorded for Brazil, in white sand campinas in the state of Roraima.

KEY WORDS: Amazonia, Brazil, Guiana Shield, Poales, Roraima

\section{INTRODUCTION}

Monotrema Körn. is a small genus of Rapateaceae and comprises four species and an interspecific hybrid. These taxa occur in the Guiana Shield region, especially in southern Venezuela and adjacent regions of Colombia and Brazil (Berry 2004).

Monotrema bracteatum Maguire was described based on collections from wet savannas from Yapacana, Amazonas State, Venezuela. Later, Maguire (1982), in his treatment of Rapateaceae for the Flora of Venezuela, recognized an infraspecific taxon, named $M$. bracteatum subsp. major Maguire. This taxon was described for few specimens from the savannas of Río Atabapo, also in the Venezuelan State of Amazonas. Since then, the name $M$. bracteatum subsp. major has been accepted and used in floristic treatments (e.g.,
Berry 2004). According to Maguire (1982) and Berry (2004), M. bracteatum subsp. major differed from $M$. bracteatum subsp. bracteatum in having both wider leaves and primary (outermost) bracts of the inflorescence (both $>$ $6.0 \mathrm{~mm}$ wide).

During the ongoing floristic study of Rapateaceae in Roraima State, Brazil (Rodrigues \& Flores 2010), I participated of an expedition to Serra da Mocidade National Park (SMNP), and observed a population of Monotrema bracteatum in the field. Other new collections of $M$. bracteatum are now available in Brazilian herbaria, specially from the adjacent Viruá National Park (VNP). In this note, I analyzed collections at MIRR and UFRR, and additionally, digitalized images of types and other specimens from NY, US, K, $\mathrm{RB}, \mathrm{UEC}$. 


\section{RESULTS AND DISCUSSION}

Monotrema bracteatum has been recently added to Brazilian flora (Oriani \& Scatena 2013). Previously, only two species of Monotrema had been recorded in Brazil (Berry 2004, Monteiro 2014), M. aemulans Körnicke and $M$. xyridoides Gleason. The primary bracts of the inflorescence provide the two diagnostic characters of $M$. bracteatum (Figure 1): they range from 20-35 $\mathrm{mm}$ long and are longer than the heads (Maguire 1958, Berry 2004). Monotrema bracteatum comprises perennial herbs 30-60 cm high, with outer bracts green, inner white, and petals pale yellow. It occurs in lowland partially open scrub savannas, on wet or flooded soils. Especially in Brazil, it is found in Rio Branco basin campinas, in open grassy to shrubby formations on white sandy soils.

A nomenclatural issue arose when reading the protologue in Maguire (1982). According to McNeill et al. (2012: art. 39), M. bracteatum subsp. major was not validly published. Maguire (1982) described it in Spanish ("Láminas de la hoja 6,0-12,0 mm. de ancho, brácteas involucrales primarias $6,0-9,0 \mathrm{~mm}$. de ancho") and did not provide a reference to a previous Latin description or diagnosis. Another observation is that the infraspecific epithet should be "majus", since Monotrema is a neuter noun according to McNeill et al. (2012: art. 24.2.).

Regarding the features used by Maguire (1982) and Berry (2004) to separate the two subspecies of $M$. bracteatum from each other, I observed instances of overlapping in the leaf width and primary bract width. This overlap occurs in specimens from different Roraiman sites, and particularly collections from SMNP were difficult to fit conveniently under any subspecies. For example, different specimens (Schütz Rodrigues et al. 2450) at UFRR and MIRR possessed leaves with $3-8 \mathrm{~mm}$ wide, and primary bracts with $4.5-8.3 \mathrm{~mm}$ wide (Figure 1). A similar intermediate condition was observed in some specimens from VNP (e.g., Barbosa \& Costa 1281; Damasco et al. 1317).

After having checked the type material of both subspecies, there is evidence for considering the Venezuelan materials as extreme forms of a more geographical spread and variable taxon. Since I have not been able to recognize infraspecific taxa within $M$. bracteatum, I refrain from validating $M$. bracteatum subsp. major.
Monotrema bracteatum Maguire, Memoirs of the New York Botanical Garden 10: 47. 1958.

Type: VENEZUELA. AMAZONAS: Cerro Yapacana, Rio Orinoco; Yapacana Savanna II, 20 Nov. 1953, B. Maguire, J.J. Wurdack \& G.S. Bunting 36624 (holotype NY!, isotypes: K!, NY!, RB!, US!, VEN).

Monotrema bracteatum var. major Maguire in Luces \& Steyermark, Flora de Venezuela 11 (2): 175. 1982, nom. nud.

Additional specimens examined: BRAZIL. RORAIMA: Caracaraí, Parque Nacional da Serra da Mocidade, Rio Capivara, 8 Dec. 2013, R. Schütz Rodrigues et al. 2450 (MIRR, UFRR); Parque Nacional do Viruá, 25 Jan. 2011, S.M. Costa \& K.G. Cangani 887 (UEC); Parque Nacional do Viruá, Rio Anauá, 27 Mar. 2011, T.D.M. Barbosa \& S.M. Costa 1417 (INPA, UEC); Parque Nacional Viruá, Estrada da perdida, Trilha, 22 Feb. 2013, G. Damasco et al. 1317 (INPA); Parque Nacional do Viruá, 22 Jul. 2010, T D.M. Barbosa \& S.M. Costa 1281 (INPA, UEC, UFRR); Parque Nacional do Viruá, 4 Dec. 2009, N.C. Dávila et al. 5845 (INPA, UFRR); VENEZUELA. AMAZONAS: Cerro Yapacana, Río Orinoco, Yapacana savanna III, 31 Dec. 1950, B. Maguire et al. 30490 (RB); Rio Atabapo, frequent in Sabana Caname on left bank of Cano Caname (Rio Atabapo $5 \mathrm{~km}$ below Guarinumo), 8 Jun. 1959, J.J. Wurdack \& L.S. Adderley 42853 (RB); in Sabana Cumare on right bank of Caño Cumare (20 kilometers above San Fernando de Atabapo), 5 Aug. 1959, J.J. Wurdack \& L.S. Adderley 43771 (NY, "holotype" of $M$. bracteatum subsp. major).

\section{ACKNOWLEDGMENTS}

I thank Instituto Chico Mendes de Conservação da Biodiversidade, especially the Parque Nacional da Serra da Mocidade staff, for facilities during the "Terra Incognita" expedition in December 2013 (collecting authorization 42090-1). 


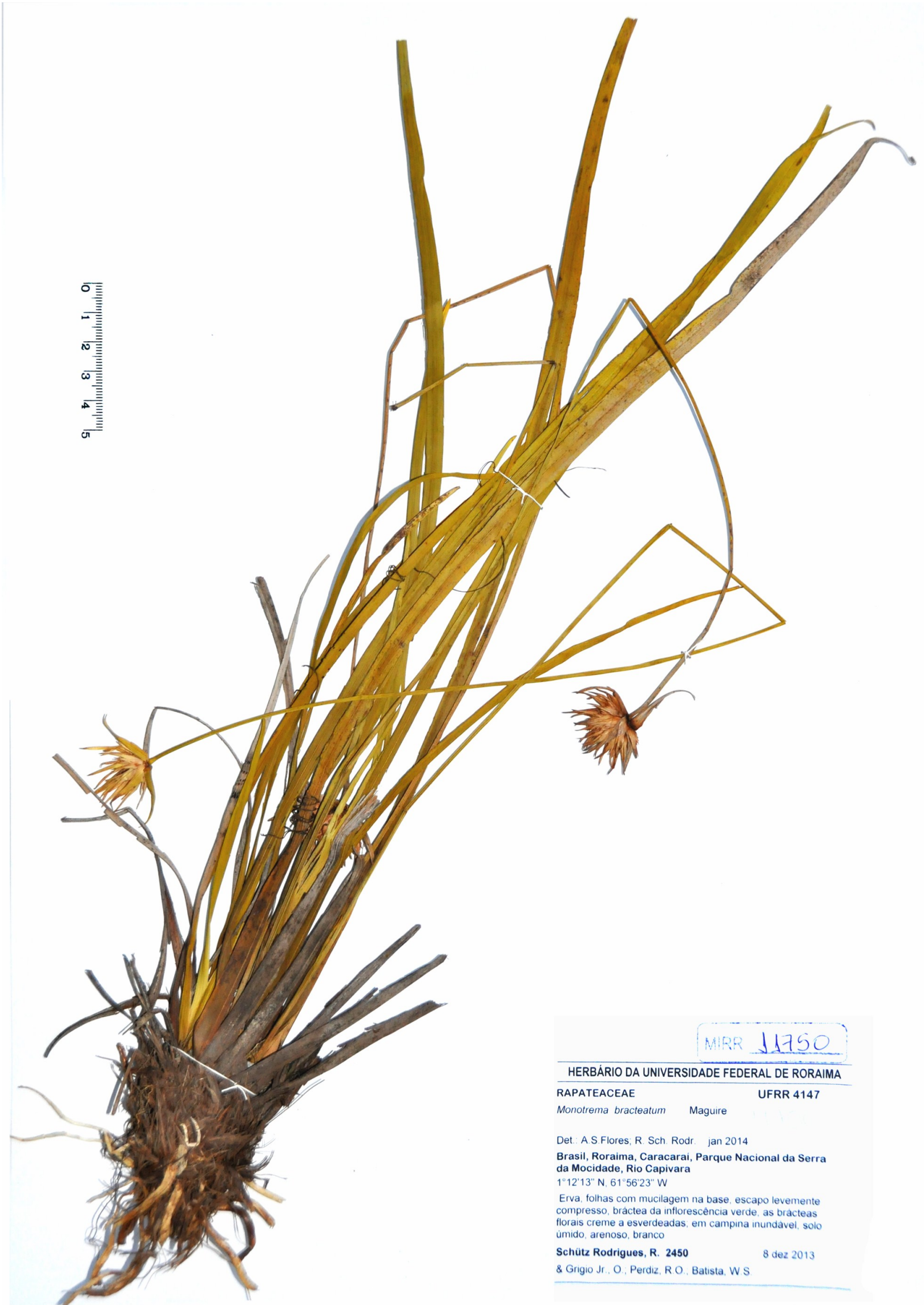

Figure 1. Monotrema bracteatum Maguire (Rapateaceae). Specimen from the Serra da Mocidade National Park, Roraima, Brazil (Schütz Rodrigues et al. 2450, MIRR). 


\section{REFERENCES}

Berry, P.E. 2004. Rapateaceae. In: Berry, P.E., Yatskievych, K. \& Holst, B.K. (Eds.). Flora of the Venezuelan Guayana, vol. 8. Missouri Botanical Garden Press, St. Louis, p. 413-472.

Maguire, B. 1958. Rapateaceae. In: Maguire, B. \& Wurdack, J.J. (Eds.). The botany of the Guayana Highland, part 3. Memoirs of the New York Botanical Garden 10: 19-49.

Maguire, B. 1982. Rapateaceae. In: Luces de Febres, Z. \& Steyermark, J.A. (Eds.) Flora de Venezuela, vol. 11(2). Ediciones Fundación Educación Ambiental, Caracas, p. 85-203.

McNeill, J., Barrie, F.R., Buck, W.R., Demoulin, V., Greuter, W., Hawksworth, D.L., Herendeen, P.S., Knapp, S., Marhold, K., Prado, J., Prud'homme van Reine, W.F., Smith, G.F., Wiersema, J.H. \& Turland, N.J. 2012. International Code of Nomenclature for algae, fungi and plants (Melbourne Code) adopted by the Eighteenth International Botanical Congress Melbourne, Australia, July 2011. Regnum Vegetabile 154: 1-240.

Monteiro, R.F. 2014. Rapateaceae. Lista de Espécies da Flora do Brasil, Jardim Botânico do Rio de Janeiro, Brazil. (http://floradobrasil.jbrj.gov.br/jabot/ floradobrasil/FB205). Access on 24 November 2014.

Oriani, A. \& Scatena, V.L. 2013. The taxonomic value of floral characters in Rapateaceae (PoalesMonocotyledons). Plant Systematics and Evolution 299(2): 291-303.

Rodrigues, R.S. \& Flores, A.S. 2010. Novas ocorrências de Rapateaceae para o Brasil. Acta Botanica Brasilica 24(4): 1096-1099. 